\title{
THE EFFECT OF PRODUCT DIVERSIFICATION STRATEGY, FINANCIAL LEVERAGE, FIRM SIZE,AND CAPITAL STRUCTURE ON PROFITABILITY
}

\begin{tabular}{|c|c|}
\hline & $\begin{array}{l}\text { in }{ }^{1} \text {, Trisandi Eka Putri }{ }^{2} \text {, Sri Mulyati } \\
\text { taatmadja, Subang - Indonesia } \\
\text { estya.as@gmail.com }\end{array}$ \\
\hline INFO ARTIKEL & ABSTRACT \\
\hline $\begin{array}{l}\text { Histori Artikel : } \\
\text { Tgl. Masuk : } 31 \text { Januari } 2021 \\
\text { Tgl. Diterima : } 15 \text { Februari } 2021 \\
\text { Tersedia Online : } 31 \text { Maret } 2021 \\
\text { Keywords: } \\
\text { Produk strategy diversification, } \\
\text { Financial leverage, Firm size, } \\
\text { Capital Structure, Probability. }\end{array}$ & $\begin{array}{l}\text { This study aims to determine the effect of product } \\
\text { diversification strategies, financial leverage, company size, } \\
\text { and capital structure on profitability (Case Study of } \\
\text { Consumer Goods Industry Sector Companies listed on the } \\
\text { Indonesia Stock Exchange for the } 2014-2018 \text { period). } \\
\text { In this study, using purposive sampling method, and } \\
\text { samples that fit the criteria were } 32 \text { companies, so that } 160 \\
\text { data were obtained on consumer goods industrial } \\
\text { companies for the period } 2014-2018 \text {. And the data were } \\
\text { analyzed using Eviews } 9 \text { program. The method of analysis } \\
\text { used in this research is descriptive statistical analysis, } \\
\text { panel regression analysis and classical assumption test. } \\
\text { The results showed the coefficient of determination R2 was } \\
14 \% \text { and the remaining } 86 \% \text { was explained by other } \\
\text { variables. Partial results (t test), product diversification } \\
\text { strategy variables and financial leverage have a positive } \\
\text { and significant effect on profitability, firm size has a } \\
\text { negative and significant effect on profitability. Meanwhile, } \\
\text { capital structure has no significant effect on profitability. The } \\
\text { simultaneous test results (F test) show that the product } \\
\text { diversification strategy, financial leverage, company size } \\
\text { and capital structure simultaneously affect profitability. }\end{array}$ \\
\hline
\end{tabular}

\section{PENDAHULUAN}

Pertumbuhan ekonomi suatu negara sering dijadikan sebagai tolak ukur untuk mengetahui sejauh mana perkembangan suatu negara, yang menyebabkan semua negara berusaha memperkuat diri khususnya dari segi ekonomi. Perekonomian di dunia mengalami ketidakstabilan yang signifikan sehingga menyebabkan pertumbuhan perekonomian semua negara di dunia mengalami naik-turun yang tidak stabil, tidak terkecuali di Indonesia. Adapun perekonomian di Indonesia sekarang sedang mengalami gelombang pasang surut indikatornya seperti kesempatan kerja, investasi, tabungan,tingkat suku bunga dan besarnya anggaran negara menjadi salah satu penyebab pasang surutnya pertumbuhan ekonomi di Indonesia. Hal ini dapat terlihat dari data Badan Pusat Statistik (BPS) pertumbuhan ekonomi di indonesia pada tahun 2011 sebesar 6,17\%, pada tahun 2012 mengalami penurunan sebesar $6,03 \%$, selanjutnya tahun 2013 sebesar 5,56\%, tahun 2014 sebesar 5,01\%, dan pada tahun 2015 mengalami penurunan yang sangat drastis sebesar $4,88 \%$, selanjutnya mengalami kenaikan kembali pada tahun 2016 sebesar 5,03\%, tahun 2017 sebesar $5,07 \%$, pada tahun 2018 sebesar 5,17\% dan pada tahun 2019 mengalami 
penurunan yang sangat drastis sebesar $5,02 \%$. Berkembangnya teknologi dan informasi sekarang membuat industri setiap perusahaan yang ada di Indonesia semakin berkembang untuk saling bersaing dalam memajukan perusahaannya. Dan setiap perusahaan yang bergerak dibidang industri, perdagangan maupun jasa memiliki tujuan utama yaitu mengembangkan usahanya dan memperoleh laba yang optimal guna menjaga kelangsungan hidup perusahaan di masa yang akan datang.

Dengan adanya kondisi

pertumbuhan ekonomi saat yang sedang tidak stabil, profitabilitas bisa menjadi salah satu acuan dalam mengukur besarnya laba menjadi begitu penting untuk mengetahui apakah perusahaan itu telah menjalankan usahanya secara efisien.Efisiensi sebuah usaha baru dapat diketahui setelah membandingkan laba yang diperoleh dengan aset atau modal yang menghasilkan laba tersebut. Sama hal nya seperti pernyataan Sastra (2014:64) dimana keberhasilan suatu perusahaan seringkali dinilai dengan besarnya profitabilitas yang dilaporkan. Profitabilitas yang tinggi dapat mencerminkan kinerja perusahaan yang baik, dimana keunggulan dalam persaingan usaha dapat mempengaruhi keberlangsungan hidup suatu perusahaan.

Tingkat profitabilitas yang semakin tinggi dapat menunjukan kinerja perusahaan semakin baik dan dengan demikian dapat menarik para investor untuk saling bekerjasama memajukan perusahaan (Sari,2017). Persaingan bisnis yang ketat ini membuat para pengusaha berlomba-lomba dalam memikirkan cara agar dapat mendapatkan profit yang sangat besar dengan cara mengurangi sedikit berbagai pertimbangan-pertimbangan dalam mengambil keputusan. Dalam resiko jangka panjang mungkin akan dirasakan oleh beberapa perusahaan yang tidak dipikirkan terlebih dahulu baik-baik langkah apa yang akan diambil agar profitabilitas perusahaan dapat meningkat dan dapat bersaing dengan perusahaan kompetitor dipasar dan di era globalisasi ini juga memaksa perusahaan untuk selalu mengembangkan berbagai macam cara dalam berbisnis agar dapat memperoleh profit yang besar. Oleh karena itu, setiap perusahaan tentunya memiliki keinginan untuk melaporkan profitabilitasnya dengan laba yang baik, agar bisa menarik minat investor untuk menanamkan modalnya. Dalam hal ini profitabilitas merupakan rasio untuk menilai kemampuan dalam mencapai keuntungan, rasio ini juga memberikan ukuran tingkat efektivitas manajemen suatu perusahaan. Hal ini ditunjukan oleh laba yang dihasilkan dari penjualan dan investasi, intinya dalam penggunaan rasio ini menunjukan efektivitas perusahaan (Kasmir, 2015:16). Dalam penelitian ini profitabilitas diukur dengan menggunakan rumus ROE (return on equity) mengukur kemampuan perusahaan dalam memperoleh laba yang tersedia bagi pemegang saham. Apabila ROE semakin tinggi maka akan semakin baik, dan hal ini membuat posisi perusahaan akan semakin kuat (Sartono, 2010:124). Pertumbuhan ROE akan menggambarkan prospek perusahaan yang cemerlang, apabila perusahaan tersebut memiliki kemampuan untuk memberikan keuntungan bagi perusahaan. Jika hal ini terjadi dapat memberikan sinyal yang positif bagi investor serta kreditur akan merasa aman memberikan pinjamannya kepada perusahaan tersebut.

Adapun beberapa penelitian terdahulu mengenai profitabilitas menunjukan hasil yang berbeda-beda. Penelitian yang dilakukan oleh Darmajati (2019) yang berjudul " Pengaruh Leverage, Diversifikasi Produk Dan Ukuran Perusahaan Terhadap Profitabilitas" Hasil penelitian ini menyatakan bahwa leverage dan ukuran perusahaan berpengaruh positif terhadap profitabilitas sedangkan diversifikasi produk berpengaruh negatif terhadap profitabilitas. Penelitian Arifin (2018) yang berjudul "Pengaruh Likuiditas, Leverage, Ukuran Perusahaan Dan Pertumbuan Penjualan Terhadap Profitabilitas" Hasil penelitia menyatakan bahwa likuidtas dan leverage berpengaruh negatif terhadap profitabilitas sedangkan ukuran 
perusahaan dan pertumbuhan penjualan berpengaruh positif terhadap profitabilitas. Penelitian Samsu (2019) yang berjudul "Pengaruh Struktur Modal Terhdap Profitabilitas" hasil penelitian ini menunjukan bahwa struktu modal tidak berpengaruh terhadap profitabilitas.

Perusahaan sektor Industri Barang
Konsumsi mengalami penurunan.

Berdasarkan data Nielsen Indonesia pertumbuhan barang konsumsi tahun 2004-2017 mengalami pasang surut, dimana pada tahun 2017 hanya tumbuh $2,7 \%$ dibandingkan periode tahun sebelumnya. Dikarenakan masyarakat yang berpenghasilan rendah yang memegang porsi terbesar mengalami penurunan pendapatan dampak naiknya harga kebutuhan seperti sewa rumah maupun turunnya uang lembur karena efisiensi perusahaan. Hal ini membuat mereka terpaksa harus menahan dan mengurangi konsumsi barang di luar kebutuhan pokok.Jadi, melemahnya daya beli masyarakat bukan akibat maraknya belanja online, tapi karena sebab pangsa pasar perdagangan digital (e-commerce) hanya satu persen dari total perdagangan ritel offline.

Salah satu perusahaan industri barang dan konsumsi sektor kosmetik serta rumah tangga ialah PT Unilever Indonesia Tbk yang memproduksi makanan, minuman, pembersih serta perawatan badan. Dan perusahaan tersebut sudah merilis laporan keuangan kuartal III 2019, dalam laporannya laba bersih industri tercatat sebesar Rp 5,5 triliun, angka ini anjlok $24,4 \%$ dibanding periode yang sama pada tahun kemudian ( year on year/ yoy) yang menggapai $R p$ 7,28 triliun. Turunnya laba bersih perseroan diakibatkan oleh melemahnya nilai penjualan, tercatat penjualan industri benda mengkonsumsi (Fast Moving Consumer Goods/ FMCG) tersebut sebesar Rp 32,3 triliun ataupun turun 2,4\% secara yoy ( year over year).

Dan menurut data laporan keuangan dari Sari,2017 yang mana pada tahun 2011 hingga tahun 2015 persentase jumlah perusahaan yang melakukan strategi diversifikasi produk mengalami peningkatan. Hal ini akan menunjukkan bahwa banyak perusahaan pada sektor industri barang konsumsi yang menerapkan strategi diversifikasi dalam meningkatkan keunggulan kompetitifnya untuk dapat memenangkan kekuatan pasar. Ketika perusahaan mampu unggul dalam persaingan maka hal ini dapat berdampak positif bagi nilai perusahaan dimana penjualan perusahaan akan mengalami peningkatan dan berdampak pada profitabilitas perusahaan. Dengan demikian, perusahaan dapat menciptakan pola pertumbuhan secara berkelanjutan.

Oleh karena itu, dengan pertumbuhan ekonomi saat yang sedang tidak stabil, profitabilitas bisa menjadi salah satu acuan dalam mengukur besarnya laba menjadi begitu penting untuk mengetahui apakah perusahaan itu telah menjalankan usahanya secara efisien. Karena, apabila tingkat dari profitabilitas yang semakin tinggi dapat menunjukan kinerja perusahaan semakin baik dan dengan demikian dapat menarik para investor untuk saling bekerjasama memajukan perusahaan.

\section{KERANGKA TEORITIS DAN PENGEMBANGAN HIPOTESIS}

\section{Landasan Teori}

\section{Signalling Theory}

Teori Sinyal memberikan cerminan jika sinyal maupun isyarat ialah sesuatu tindakan yang diambil manajemen industri yang memberi petunjuk untuk investor tentang gimana manajemen memandang prospek industri. Teori ini mengatakan kalau investor bisa membedakan antara industri yang mempunyai nilai besar dengan industri yang mempunyai nilai rendah (Brigham serta Houston, 2013:31). Suatu Industri terdorong untuk membagikan data laporan keuangan kepada pihak eksternal disebabkan terdapatnya teori sinyal. Teori Sinyal didasarkan pada anggapan kalau data yang diterbitkan oleh perusahaan tentunya akan diterima oleh para pengguna laporan keuangan ataupun oleh pihak tidak sama. Hal ini diakibatkan sebab terdapatnya asimetri dari data tersebut. Data tersebut 
bisa pengaruhi pengambilan keputusan investasi para investor. Dimana kualitas data dalam laporan keuangan bisa dinilai dari berbagai sudut pandang seperti keakuratan, relevan, kelengkapan data serta ketepatan waktu (Connelly et al., 2011)

\section{Market Power Theory}

Montgomery (1994) dalam Harto (2005), terdapat tiga perspektif motif diversifikasi perusahaan salah satunya yaitu Teori Kekuatan Pasar (Market Power Theory). Teori kekuatan pasar merupakan salah satu teori ekonomi. Menurut Montgomery (1994) dalam Harto (2005) memandang bahwa "kekuatan pasar melihat diversifikasi sebagai alat untuk menumbuhkan pengaruh anti kompetisi yang bersumber pada kekuatan konglomerasi”.

\section{Pecking Order Theory}

Pecking order theory merupakan suatu kebijakan yang ditempuh oleh suatu perusahaan untuk mencari tambahan dana dengan cara menjual aset yang sudah dimiliki. Dan menjual aset tersebut akan dimungkinkan ketika aset yang perusahaan miliki berada dalam keadaan yang mencukupi, sehingga penjualan tersebut tidak akan berpengaruh terhadap kondisi keuangan perusahaan secara jangka pendek. Aset-aset yang bisa dijual untuk memenuhi kebutuhan perusahaan misalnya gedung, tanah, peralatan dan aset-aset lainnya termasuk dengan menerbitkan dan menjual saham di pasar modal, dan dana yang berasal dari laba ditahan (Fahmi, 2012:192). Pecking order theory menyatakan bahwa manajer keuangan lebih suka menggunakan dana internal daripada dana dari pihak eksternal.

\section{Profitabilitas}

Menurut Darmajati (2019) profitabilitas yang di proksian dengan $\mathrm{ROE}$ (Rerturn on Equity) merupakan total laba bersih setelah pajak dibagi dengan total ekuitas di kali dengan 100\%. Dengan rumus :

$$
\mathrm{ROE}=\frac{\text { Laba Bersih Setelah Pajak }}{\text { Total Ekuitas }} X 100 \%
$$

Sumber : Darmajati (2019)

\section{Strategi Diversifikasi Produk}

Menurut Harto (2005) rumus untuk mencari diversifikasi diukur dengan menggunakan rumus Hirschman Herfindahl Index (HHI). $\mathrm{HHI}$ dihitung dengan jumlah dari kuadrat masingmasing segmen dibagi dengan kuadrat total penjualan perusahaan. Dengan rumus :

$$
\mathrm{HHI}=\frac{\sum_{i=1}^{n} \text { segsales }^{2}}{\sum_{i=1}^{n}(\text { sales })^{2}}
$$

Sumber : Harto (2005)

\section{Financial Leverage}

Menurut Harto (2005) financial leverage dapat diukur dengan menggunakan debt to asset ratio (DAR). DAR dapat dicari dengan membandingkan seluruh total hutang dibagi dengan total asset dikali 100\%. Dengan rumus :

DAR $=\frac{\text { Total Utang }}{\text { Total Asset }} \times 100 \%$

\section{Ukuran Perusahaan}

Menurut Darmajati (2019) ukuran perusahaan dapat diukur dengan menggunakan logaritma (LN) dari total aset. Dengan rumus :

Ukuran Perusahaan $=$ Ln Total Asset

\section{Struktur Modal}

Menurut Prabowo (2019) struktur modal dapat diukur dengan debt to equity ratio (DER). DER dapat dicari dengan membandingkan seluruh total hutang dibagi dengan total ekuitas dikali $100 \%$. Dengan rumus :

$\mathrm{DER}=\frac{\text { Total Utang }}{\text { Total Ekuitas }} \times 100 \%$ 
Pengembangan Hipotesis

\section{Pengaruh Strategi Diversifikasi Produk Terhadap Profitabilitas}

Strategi diversifikasi produk merupakan upaya dalam mengembangkan suatu produk atau memperluas pasar dengan produk yang baru, yang mana tujuan dari keduanya untuk memperbesar pertumbuhan dalam peningkatan penjualan produk dan fleksibilitas (Tjiptono 2014:132).

Dalam penelitian Novi Puspita Sari (2017) menyatakan bahwa strategi diversifikasi produk berpengaruh positif terhadap profitabilitas. Strategi diversifikasi dilakukan oleh perusahan sebagai salah satu cara untuk melakukan ekspansi usaha dan memperluas pasar Ketika perusahaan mampu unggul dalam persaingan maka hal ini akan dapat berdampak positif bagi nilai perusahaan dimana penjualan perusahaan akan mengalami peningkatan dan berdampak pada profitabilitas perusahaan. Dengan demikian perusahaan dapat menciptakan pola pertumbuhan secara berkelanjutan. Oleh karena itu, terdapat hubungan positif antara strategi diversifikasi produk terhadap profitabilitas.

$\mathrm{H} 1$ : Strategi diversifikasi produk berpengaruh positif terhadap profitabilitas

\section{Pengaruh Financial Leverage Terhadap Profitabilitas}

Financial leverage yaitu penggunaan assets dan sumber dana (sources of funds) yang dilakukan perusahaan yang mana perusahaan itu memiliki biaya tetap (beban tetap) dengan maksud agar meningkatkan keuntungan potensial pemegang saham (Musthafa 2017:89).

Dalam penelitian Arifin (2018) menyatakan bahwa Penggunaan utang yang terlalu tinggi akan membahayakan bagi perusahaan, yang mana perusahaan tersebut akan masuk kedalam kategori extreme leverage (utang ekstrim) yang merupakan suatu perusahaan tersebut telah terjebak dalam lingkup hutang yang tinggi dan sulit untuk melepaskan beban utang tersebut. Dan menurunkan respon investor dalam hal menerima sinyal berupa good news dari perusahaan dan tentunya dapat menyebabkan perusahaan mengalami resiko kebangkrutan. Akan tetapi, apabila perusahaan dengan tingkat financial leverage yang lebih kecil dari nilai asetnya adalah perusahaan yang solvable. Artinya apabila financial leverage rendah maka akan menghasilkan laba yang besar dan hal itu mencerminkan kinerja perusahaan yang baik. Oleh karena itu, terdapat hubungan negatif antara financial leverage terhadap profitabilitas.

$\mathrm{H} 2$ : Financial leverage berpengaruh positif terhadap profitabilitas

\section{Pengaruh Ukuran Perusahaan Terhadap Profitabilitas \\ Ukuran perusahaan merupakan} ukuran besar kecilnya perusahaan yang dapat ditunjukan serta dapat dinilai oleh total asset, total penjualan, jumlah laba, beban pajak dan lain-lain. (Brigham \& Houston 2010:4).

Dalam penelitian Darmawan (2018) menyatakan bahwa Apabila aset yang dimiliki perusahaan semakin besar maka laba yang akan didapatkan juga besar dan perusahaan yang berukuran besar tentunya dapat memiliki berbagai macam kelebihan dibandingkan dengan perusahaan yang kecil. Sedangkan menurut penelitian Boutilda (2014) perusahaan dengan total aset yang kecil belum tentu memiliki tingkat keuntungan yang lebih kecil dibandingkan perusahaan dengan total aset yang besar,selama aset yang digunakan sebaik mungkin dengan produksi jumlah yang besar namun dapat meminimalisir biaya produksinya. Oleh karena itu, terdapat hubungan positif antara ukuran perusahaan terhadap profitabilitas.

H3 : Ukuran Perusahaan berpengaruh positif terhadap profitabilitas

\section{Pengaruh Struktur Modal Terhadap Profitabilitas}


Struktur modal merupakan pendanaan ekuitas dan utang pada suatu perusahaan yang sering dihitung berdasarkan besaran relatif berbagai sumber pendanaan Subramanyam (2014:106).

Dalam penelitian Samsu (2019) menyatakan bahwa struktur modal yang optimal tentunya mempunyai keterkaitan dengan hutang yang terdapat di perusahaan, ialah hutang jangka panjang. Struktur modal bisa diukur dengan Debt to equity ratio (DER) merupakan rasio buat memperhitungkan hutang serta ekuitas. Dengan ini, terdapatnya pemakaian hutang bisa pengaruhi sesuatu resiko dan keuntungan yang hendak diperoleh industri. Oleh karena itu, apabila hutang naik maka profitabilitas turun, kebalikannya apabila hutang turun maka profitabilitas naik. Oleh karena itu, terdapat hubungan negatif antara struktur modal terhadap profitabilitas.

H4 : Struktur Modal berpengaruh negatif terhadap profitabilitas

\section{METODOLOGI PENELITIAN}

\section{Metodologi Penelitian}

Penelitian ini menggunakan jenis data kuantitatif, sedangkan jenis data dalam penelitian ini menggunakan sumber data sekunder. Data sekunder yang digunakan dalam penelitian ini merupakan data dalam bentuk laporan keuangan tahunan perusahaan sektor industry barang konsumsi yang terdaftar di Bursa Efek Indonesia periode 2014-2018. Sumber data dalam penelitian ini diperoleh melalui website Bursa Efek Indonesia yaitu www.idx.co.id dan__website resmi perusahaan.

\section{Populasi dan Sampel}

Populasi dalam penelitian ini merupakan seluruh perusahaan industry barang konsumsi yang terdaftar di Bursa Efek Indonesia periode 2014-2018, sebanyak 51 perusahaan. Teknik pemilihan sample yang digunakan adalah purposive sampling dengan kriteria sebagai berikut :

\section{Tabel 1}

Kriteria Pengambilan Sampel

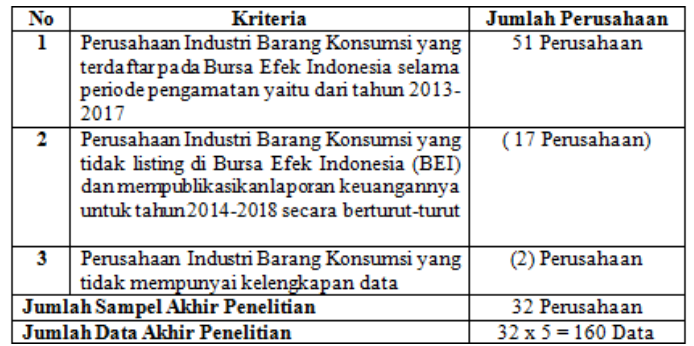

Sumber : data penelitian diolah kembali (2020)

Sehingga diperoleh jumlah sampel sebanyak 32 perusahaan, dengan periode penelitian selama 5 tahun maka diperoleh jumlah data sebanyak 160 data.

\section{Metode Analisis Data}

Data dianalisis menggunakan bantuan software Eviews 9. Metode analisis yang digunakan dalam penelitian ini adalah analisis deskriptif, pengujian model estimasi, uji asumsi klasik, analisis regresi data panel dan uji hipotesis.

\section{HASIL DAN PEMBAHASAN}

\section{Statistik Deskriptif}

Analisis statistik deskriptif dalam penelitian ini memaparkan penjelasan dari masing-masing variabel yang diteliti. Dari deskriptif statistik tersebut menghasilkan nilai mean, median, minimum, maksimum, standar deviasi, dan observations dari masing-masing variabel penelitian sebagaimana ditunjukan dalam tabel berikut ini :

Tabel 2

\section{Hasil Analisis Statistik Deskriptif}

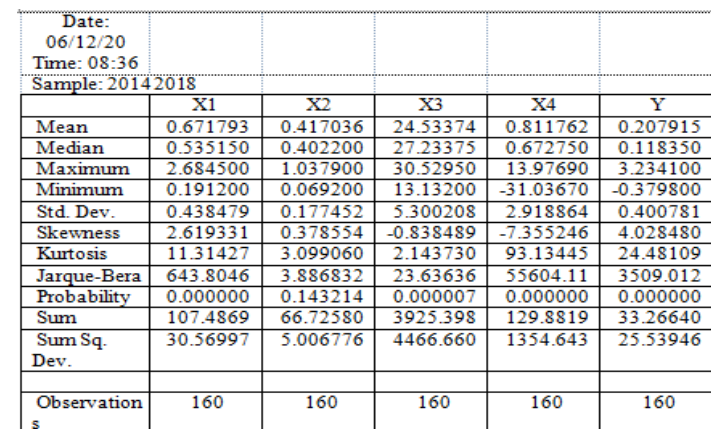

Sumber : Ouput EViews 9, 2020

\section{Uji Pemilihan Model}

Dalam membuat analisis regresi data panel, langkah pertama yang harus dilakukan adalah memilih model terbaik 
diantara Common Effect, Fixed Effect dan Random Effect.

\section{Uji Chow}

Uji ini dilakukan untuk memilih salah satu model pada regresi data panel yaitu antara model Common Effect dan Fixed Effect.

\section{Tabel 3}

Hasil Uji Chow

\begin{tabular}{|c|c|c|c|}
\hline \multicolumn{2}{|c|}{ Redundant Fixed Effects Tests } & & \\
\hline Equation: FEM & & & \\
\hline Test cross-section fixed ef & & & \\
\hline Effects Test & Statistic & d.f. & Prob. \\
\hline Cross-section F & 3.688523 & $(31,124)$ & 0.0000 \\
\hline Cross-section Chi-square & 104.549487 & 31 & 0.0000 \\
\hline
\end{tabular}

Sumber: Ouput EViews 9, 2020

Hasil uji chow menunjukan bahwa nilai probabilitas $F(0.0000)<0.05$ artinya model terbaik menurut uji chow adalah Fixed Effect Model.

\section{Uji Hausman test}

Uji ini dilakukan untuk memilih salah satu model terbaik diantara Fixed Effect dan Random Effect.

\section{Tabel 4}

Hasil Uji Hausman Test

\begin{tabular}{|c|c|c|c|}
\hline \multicolumn{3}{|c|}{ Correlated Random Effects - Hausman Test } & \\
\hline \multicolumn{4}{|c|}{$\begin{array}{l}\text { Equation: REM } \\
\text { Test cross-section random effects }\end{array}$} \\
\hline \multicolumn{3}{|c|}{ Test cross-section random effects } & \\
\hline Test Summary & $\begin{array}{l}\text { Chi-Sq } \\
\text { Statistic }\end{array}$ & Chi-Sq. d.f. & Prob. \\
\hline Cross-section random & 1.620758 & 4 & 0.8051 \\
\hline
\end{tabular}

Hasil uji hausman test didapatkan probabilitas $F$ sebesar 0.8051 hasil hausman test menunjukkan bahwa probabilitas $\mathrm{F}>5 \%$ artinya $\mathrm{HO}$ diterima dan $\mathrm{H} 1$ ditolak, sehingga model yang terbaik menurut uji hausman test adalah random effectmodel.

\section{Uji Langrange Multiplier}

Uji ini dilakukan untuk memilih salah satu model pada regresi data panel yaitu antara model Common Effect dan Random Effect.
Lagrange Multiplier Tests for Random Effects Null hypotheses: No effects

Altemative hypotheses: Two-sided (Breusch-Pagan) and one-sided (all others) altematives

\begin{tabular}{|l|l|l|l|}
\hline \hline & \multicolumn{2}{|c|}{ Test Hypothesis } \\
& Cross-section & Time & Both \\
\hline \hline Breusch-Pagan & 37.51788 & 0.029362 & 37.54724 \\
\hline & $(0.0000)$ & $(0.8639)$ & $(0.0000)$ \\
\hline
\end{tabular}

Sumber : Ouput EViews 9, 2020

Hasil uji langrange multiplier menunjukan bahwa nilai probabilitas Breusch-Pagan $(0.0000)>\alpha(0.05)$, artinya model terbaik menurut uji langrange multiplier adalah Common Effect Model.

\section{Uji Asumsi Klasik}

Menurut Gujarati \& Porter (2009) persamaan yang dapat memenuhi uji asumsi klasik hanya persamaan yang menggunakan metode Generalized Least Square (GLS). Dimana dalam pengujian eviews model estimasi yang menggunakan metode GLS yaitu random effect model, sedangkan fixed effect dan commoneffect menggunakan Ordinary Least Square (OLS). Dengan demikian perlu atau tidaknya pengujian asumsi klasik dalam penelitian ini tergantung pada hasil pemilihan metode estimasi. Apabila berdasarkan pemilihan metode estimasi yang sesuai untuk persamaan regresi adalah random effect, maka tidak perlu dilakukan uji asumsi klasik. Dalam penelitian ini sesuai dengan random effect model, sehingga tidak dilakukan uji asumsi klasik.

\section{Hasil Analisis Regresi Data Panel}

Pengujian hipotesis yang digunakan dalam penelitian ini adalah dengan menggunakan analisis regresi data panel dengan model commen effect sesuai dengan hasil uji pemilihan model. Model regresi yang digunakan sebagai berikut:

\section{Tabel 8}

Hasil Analisis Regresi Data Panel

Tabel 4

Hasil Uji Langrange Multiplier 


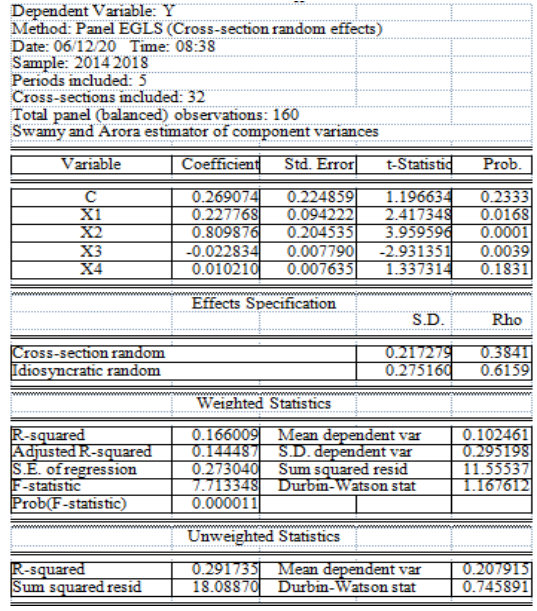

Sumber: Ouput EViews 9, 2020

Dengan persamaan model regresi data panel sebagai berikut :

ROE it $=0.269074$ it +0.227768 HHlit+ 0.809876 DARit -0.022834 SIZEit+ 0.010210 DERit+ $\varepsilon i t$

\section{Hasil Uji Hipotesis}

1. Uji F

Uji $F$ dilakukan untuk menunjukan apakah semua variabel independen yang dimasukan dalam model regresi mempunyai pengaruh secara bersamasama terhadap variabel dependen.

\section{Tabel 9}

\section{Hasil Uji F}

\begin{tabular}{|c|c|c|c|}
\hline \multicolumn{3}{|c|}{ Dependent Varisble: Y } & \\
\hline \multicolumn{4}{|c|}{ Dste: $06 / 12 / 20$ Time: 08.38} \\
\hline \multicolumn{4}{|c|}{ Sample: 20142018} \\
\hline \multicolumn{4}{|c|}{ Periods included: 5} \\
\hline \multicolumn{4}{|c|}{ Cross-sections included: 32} \\
\hline \multicolumn{4}{|c|}{ Total panel (balanced) observations: 160} \\
\hline \multicolumn{4}{|c|}{ Swamy and Arora estimator of component variances } \\
\hline F-statistic & 7.713348 & Durbin-Watson stat & 1.167612 \\
\hline Prob(F-statistic) & 0.000011 & & \\
\hline
\end{tabular}

Sumber : Ouput EViews 9, 2020

Berdasarkan uji signifikansi simultan menunjukan bahwa nilai probabilitas $F$ $(0.000011)<\alpha(0.05)$ dan nilai $F_{\text {hitung }}$ $(7.713348)>F_{\text {tabel }}$ (2.43), maka dapat disimpulkan bahwa $\mathrm{H}_{0}$ ditolak dan $\mathrm{H}_{1}$ diterima, maka dapat disimpulkan bahwa $\mathrm{H} 0$ ditolak dan $\mathrm{H} 1$ diterima, artinya variabel independen yang terdiri dari strategi diversifikasi produk, financial leverage, ukuran perusahaan dan struktur modal secara bersama-sama memperngaruhi variabel dependen yaitu profitabilitas.
2. Koefisien Determinasi

Nilai R square menunjukan seberapa besar variabel independen menjelaskan variabel dependennya.

\section{Tabel 10 Koefisien Determinasi}

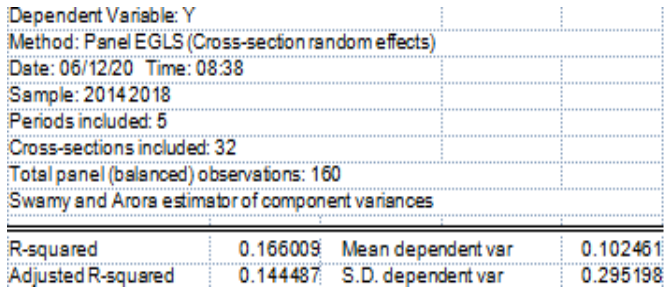

Sumber : Ouput EViews 9, 2020

Berdasarkan output koefisien determinasi menunjukan bahwa nilai adjusted $R$ square sebesar menunjukan 0.144487 atau $14 \%$ yang dapat diartikan bahwa variabel dependen yaitu profitabilitas dapat dijelaskan oleh variabel independen yaitu strategi diversifikasi produk, financial leverage, ukuran perusahaan dan struktur modal sebesar $14 \%$ sisanya $86 \%$ dijelaskan oleh variabel diluar penelitian.

\section{Uji t}

Uji t digunakan untuk mengetahui sejauh mana pengaruh suatu variabel independen terhadap variabel dependen.

\section{Tabel 11}

Uji t

\begin{tabular}{l} 
Dependent Variable: $Y$ \\
Method: Panel EGLS (Cross-section randomeffects) \\
Date: $06 / 12 / 20$ Time: 08.38 \\
Sample: 20142018 \\
Periods included: 5 \\
Cross-sections included: 32 \\
Total panel (balanced) observations: 160 \\
Swamy and Arora estimator of component variances \\
\hline \hline Variable \\
\hline \hline
\end{tabular}

Sumber : Ouput EViews 9, 2020

Berdasarkan hasil uji t, maka penarikan hipotesis secara parsial dapat disimpulkan sebagai berikut :

a. Variabel strategi diversifikasi produk (X1) menunjukan nilai thitung (2.417348) $>t_{\text {tabel }}$ (1.97539) dengan tingkat probabilitas $(0.0168)<\alpha(0.05)$. Hal ini menunjukan bahwa variabel strategi diversifikasi produk (X1) berpengaruh 
positif dan signifikan terhadap profitabilitas $(Y)$.

b. Variabel financial leverage (X2) menunjukan nilai thitung (3.959596) > $t_{\text {tabel }}$ (1.97539) dengan tingkat probabilitas $(0.0001)<\alpha(0.05)$. Hal ini menunjukan bahwa variabel financial leverage (X2) berpengaruh positif dan signifikan terhadap profitabilitas $(Y)$.

c. Variabel ukuran perusahaan (X3) menunjukan nilai thitung (-2.931351) $<t_{\text {tabel }}(1.97539)$ dengan tingkat probabilitas $(0.0039)<\alpha(0.05)$. Hal ini menunjukan bahwa variabel ukuran perusahaan (X3) berpengaruh negatif dan signifikan terhadap profitabilitas (Y).

d. Variabel struktur modal (X4) menunjukan nilai $t_{\text {hitung }}(1.337314)$ $<t_{\text {tabel }}$ (1.97539) dengan tingkat probabilitas $(0.1831)>\alpha(0.05)$. Hal ini menunjukan bahwa variabel struktur modal (X4) tidak berpengaruh signifikan terhadap profitabilitas $(\mathrm{Y})$

\section{Pembahasan}

1. Pengaruh Strategi Diversifikasi Produk Terhadap Profitabilitas

Hasil penelitian ini menunjukan bahwa secara parsial strategi diversifikasi produk berpengaruh positif terhadap arus profitabilitas, hasil ini sejalan dengan hasil penelitian Putranto (2019) dan Sari (2017). Hal tersebut menunjukan bahwa apabila semakin tinggi strategi diversifikasi perusahaan (hhi) maka perusahaan akan semakin terkonsentrasi. Dan hal ini menunjukan perusahaan industri barang konsumsi mampu menjual produkproduknya di atas tingkat persaingan yang ada dan serta dapat memenangkan pasar, dan aka berdampak pada peningkatan volume penjualan secara konsisten sehingga pertumbuhan penjualan perusahaan akan semakin tinggi dan pada akhirnya membuat tingkat profitabilitas perusahaan meningkat. Sama halnya dengan pendapatan Sari (2017) yang menyatakan bahwa perusahaan yang semakin terdiversifikasi dapat meningkatkan penjualan ketika perusahaan tersebut mempunyai kekuatan pasar di berbagai pangsa pasarnya. semakin tinggi penjualan pada segmen tertentu membuat perusahaan akan lebih unggul dibandingkan para pesaingnya, perusahaan dengan berbagai macam segmen usaha memiliki banyak opsi untuk menghasilkan laba.

\section{Pengaruh Financial Leverage Terhadap Profitabilitas \\ Hasil penelitian ini menunjukan bahwa} secara parsial financial leverage berpengaruh positif terhadap profitabilitas, hasil ini sejalan dengan hasil penelitian Harto (2005), Putranto (2019), Ritonga (2014), dan Kurniawati (2015). Hal ini menunjukan bahwa profitabilitas (return on equity) secara signifikan dapat dipengaruhi oleh financial leverage yang diproksikan dengan debt to asset ratio. Artinya, dengan meningkatkan financial leverage maka profitabilitas akan mengalami peningkatan secara nyata atau maksimal (Ritonga,2014). Karena, perusahaan dengan tingkat financial leverage yang lebih kecil dari nilai asetnya merupakan perusahaan yang solvable. Hal ini berarti investor juga melihat atau mempertimbangkan sejauh mana operasi perusahaan dibiayai dengan utang atau seberapa banyak utang perusahaan yang digunakan untuk menjalankan usahanya sebagai suatu kinerja yang penting. Berdasarkan penelitian ini, maka perusahaan perlu meningkatkan financial leverage karena semakin besar hutang yang digunakan perusahaan untuk membiayai asetnya maka akan semakin besar pula laba yang diperoleh para investor.

\section{Pengaruh Ukuran Perusahaan Terhadap Profitabilitas}

Hasil penelitian ini menunjukan bahwa secara parsial ukuran perusahaan berpengaruh negatif terhadap profitabilitas, hasil ini sejalan dengan hasil penelitian Wulandari (2017), Febria (2013), Boutilda (2014) dan Juliana (2019). Hal ini menunjukan bahwa tingkat derajat signifikansi yang dibawah 0,05 menandakan semakin maksimal ativa perusahaan maka laba yang didapat akan maksimal pula karena aktiva yang digunakan untuk operasional perusahaan. Akan tetapi, koefisien menunjukan tanda 
negatif (-) pada t hitung yang menandakan bahwa adanya pergerakan ukuran perusahaan terhadap profitabilitas. Dimana saaat ukuran perusahaan meningkat maka profitabilitas menurun, sebaliknya apabila ukuran perusahaan menurun maka profitabilitas meningkat. Berdasarkan uraian diatas, menunjukan bahwa ukuran perusahaan bukan jaminan bahwa ukuran perusahaan akan memiliki kinerja yang baik yang tercermin dari laba.

\section{Pengaruh Struktur Modal Terhadap Profitabilitas}

Hasil penelitian ini menunjukan bahwa secara parsial struktur modal tidak berpengaruh terhadap profitabilitas, hasil ini sejalan dengan hasil penelitian Siswatika (2017) dan Samsu (2019). Hal ini menunjukan bahwa struktur modal yang rendah menandakan bahwa struktur permodalan perusahaan tidak terlalu memanfaatkan hutang terhadap ekuitas. Semakin rendah sruktur modal juga menunjukan semakin kecil kewajiban atau beban hutang yang tanggung perusahaan terhadap pihak luar, sehingga dapat meningkatkan jumlah laba yang diterima oleh perusahaan. Hal ini berarti bahwa. perusahaan industri barang konsumsi menunjukkan komposisi utang yang lebih besar daripada komposisi modal sendiri.

\section{KESIMPULAN}

Berdasarkan hasil penelitian, maka dapat ditarik kesimpulan sebagai berikut :

1. Secara parsial strategi diversifikasi produk berpengaruh positif dan signifikan terhadap profitabilitas.

2. Secara parsial financial leverage berpengaruh positif dan signifikan terhadap profitabilitas

3. Secara parsial ukuran perusahaan berpengaruh negatif dan signifikan terhadap profitabilitas

4. Secara parsial struktur modal tidak berpengaruh signinfikan terhadap profitabilitas.

\section{IMPLIKASI DAN KETERBATASAN}

\section{Implikasi}

Berdasarkan hasil penelitian mengandung Implikasi bahwa kedepannya investor, dapat mempertimbangkan komponen yang terkandung dalam laporan keuangan seperti strategi diversifikasi produk,financial leverage,ukuran perusahaan dan struktur modal untuk memprediksi tingkat profitabilitas dari perusahaan tersebut. Karena tingkat profitabilitas yang semakin tinggi dapat menunjukan kinerja perusahaan semakin baik dan dengan demikian dapat menarik para investor untuk saling bekerjasama memajukan perusahaan.

\section{Keterbatasan}

Berdasarkan hasil penelitian yang telah dilakukan adapun keterbatasan dalam penelitian ini adalah sebagai berikut :

1. Penelitian ini hanya menggunakan perusahaan Sektor Industri Barang Konsumsi yang go publik yang terdaftar di BEl (Bursa Efek Indonesia) sebagai sampel

2. Masih adanya variabel lain yang belum digunakan pada penelitian yang dapat mempengaruhi profitabilitas pada perusahaan Sektor Industri Barang Konsumsi yang terdaftar di BEl (Bursa Efek Indonesia)

\section{Saran}

Berdasarkan hasil penelitian yang telah dilakukan maka peneliti memberikan saran sebagai berikut :

1. Bagi peneliti selanjutnya, disarankan untuk menambah variabel diluar penelitian ini yang diduga dapat mempengaruhi profitabilitas,sehingga dapat meningkatkan nilai koefisien determinasi dan selanjutnya hendaknya menggunakan sektor perusahaan lain yang memiliki lebih banyak populasi agar mampu menentukan sampel yang lebih banyak.

2. Bagi perusahaan, diharapkan mempertahankan serta meningkatkan mutu dari strategi diversifikasi produk perusahaan karena variabel ini mempunyai pengaruh yang dominan 
dalam mempengaruhi profitabilita. Bagi manajemen perusahaan terkait dengan penelitian ini dapat dijadikan acuan bagi pihak perusahaan untuk membuat bahan kebijakan yang strategis, sehingga optimalisasi profit perusahaan dapat tercapai dan menjaga kelangsungan hidup perusahaan.

3. Bagi investor, berdasarkan hasil penelitian ini investor dapat Dengan penelitian ini dapat dijadikan informasi mengenai investasi yang akan dilakukan oleh para investor.

\section{DAFTAR PUSTAKA}

Agus Sartono. 2010. Menejemen Keuangan Teori dan Aplikasi. Edisi 4. BPFE Yogyakarta Brigham dan Houston. (2001) Dasar-dasar Manajemen Keuangan. Buku 1 (Edisi 11). Jakarta : Salemba empat

Agustini, Fauziah, 2010. Manajemen Sumber Daya Manusia Lanjutan. Medan: Madenatera.

Agus, Widarjono. 2013. Ekonometrika Pengantar Dan Aplikasinya. Ekonosia. Jakarta.

Ajija, Shochrul R et al. 2011. Cara Cerdas Menguasai Eviews. Jakarta: Salemba Empat.

Barney dan Hesterly, 2002. Strategic Management and Competitive.

Baker, Richard E. Lembke, Valdean C. King, Thomas E. 2010. Akuntansi Keuangan Lanjutan (Perspektif Indonesia) Buku 1. Jakarta: Salemba Empat.

Brigham, E.F.dan Gapenski, LouisC. 1996. "Intermadiate finance management" (5th ed.). Harbor Drive: The Dryden Press.

Brigham, Eugene.F dan Joel F. Houston. 2001. Manajemen Keuangan. Edisi Kedelapan Buku 2. Jakarta: Erlangga.

Brigham, Eugene F dan Houston, Joel F. 2006. Dasar-dasar Manajemen
Keuangan, Edisi 10. Edisi Bahasa Indonesia, Terjemah oleh Ali Akbar Yulianto

Brigham, F. Eugene dan Joel F. Houston. 2013. Dasar-dasar Manajemen Keuangan. Jakarta: Salemba Empat.

Connelly, Brian L., et al. "Signaling theory: A review and assessment." Journal of Management 37.1 (2011): 39-67

Dr. Kasmir. (2015), Analisis Laporan Keuangan. Jakarta: Rajawali Pers

Damodar N. Gujarati and Dawn C. Porter. 2012. Dasar-dasar Ekonometrika. Jakarta Salemba Empat.

Fahmi, Irham. (2014).Analisis Kinerja Keuangan.Cetakanke-2, Bandung :Alfabeta

Fahmi, Irham. (2015). Analisis Laporan Keuangan, Cetakan Ke-5. Bandung : Alfabeta.

Ghozali, Imam. (2016). Aplikasi Analisis Multivvariete Dengan Program IBM SPSS 23. Edisi VIII. Badan Penerbit Universitas Diponogoro. Semarang.

Ghozali, Imam. (2013). Aplikasi Analisis Multivariate dengan Program. Edisi Ketujuh. Semarang: Badan Penerbit Undip.

Husnan, Suad dan Enny Pudjiastuti. 2012. Dasar-Dasar Manajemen Keuangan. Edisi Keenam. Cetakan Pertama. Yogyakarta: UPP STIM YPKN

Harahap, Sofyan Syafri. 2015. Analisis Kritis atas Laporan Keuangan. Edisi 110. Jakarta: Rajawali Pers.

Ikatan Akuntansi Indonesia. (2009), Standar Akuntansi Keuangan, PSAK No.1 : Penyajian Laporan Keuangan. Jakarta : Salemba Empat

Jogiyanto. 2000. "Teori Portofolio dan Analisis Investasi". Yogyakarta: BPFE UGM. 
Learned, E., Christensen, C.R., Andrews, K., and Guth, W. 1965. Business Policy Text \& Cases. Irwin, Homewood, IL, USA.

Munawir, S. 2007. Analisa Laporan Keuangan. Edisi Keempat. Liberty. Yogyakarta.

Musthafa. 2017. Manajemen Keuangan. Yoygyakarta : CVAndi Offset.

Myers, S. c., 1984, "Capital Structure Puzzle", Journal of Finance, 39 (3), July, pp 575-592.

R.S.H.J. Nijman,S.E. Van Der Work, Strategi Pemasaran Modern, (Jakarta : Erlangga 1997)

Sugiyono. (2016). Metode Penelitian Kuantitatif, Kualitatif, dan Kombinasi Mixed Methods). Bandung. Alffabeta.

Tjiptono, Fandy. 2014, Pemasaran Jasa Prinsip, Penerapan, dan Penelitian, Andi Offset, Yogyakarta.

Tjiptono, Fandy. 2008. Strategi Pemasaran (edisi 3). Andi. Yogyakarta

Winarno, Wing Wahyu. 2009. Analisis Ekonometrika dan Statistika dengan Eviews. Yogyakarta: UPP STIM YKPN.

Arifin, S.D., M, Amalia Riski (2018). Pengaruh Likuiditas, Leverage, Ukuran Perusahaan Dan Pertumbuhan Penjualan Terhadap Profitabilitas. Jurnal akuntansi.Vol No.1

Boutilda.R, Imo G (2014) Pengaruh Struktur Modal Terhadap Profitabilitas : Studi Empiris Perusahaan-Perusahaan Manufaktur Yang Terdaftar Di Bursa Efek Indonesia Periode 2009-2013.

Febria, Rirind L. Pengaruh Leverage Dan Ukuran Perusahaan Terhadap Profitabilitas. Jurnal Ekonomi

Harto, P. (2005). Kebijakan Diversifikasi Perusahaan dan Pengaruhnya terhadap Kinerja :Studi empiris pada perusahaan publik di Indonesia. SNA, 297-307.
Hermawan, Lucius. 2015. Dilema Diversifikasi Produk : Meningkatkan Pendapatan Atau Menimbulkan Kaniblisme Produk. Universitas $\mathrm{Ma}$ Chung

Itung,S., dan Lasdi,L (2018). Pengaruh Strategi Diversifikasi Dan Kepemilikan ManajerialTerhadap Kinerja Perusahaan Yang Dimoderasi Oleh Struktur Modal. JurnalAkuntnasi Komptemporer. Vol 10 No.2.

Iswanaji, C. 2018. Pengaruh Struktur Modal Terhadap Profitabilitas Dan Finanial Leverage Pada Bank Syariah Di Yoyakarta. Journal of Islamic Economics. Vol 2 No 1. Hal 81-93

Jagat, S. dan Darmajati, J (2019). Pengaruh Leverage, Diversifikasi Produk Dan Ukuran Perusahaan Terhadap Profitabilitas. Journal of applied managerial accounting. Vol. 3, No. 1 page 97-106

Juliana,A dan Melisa. Analisis FaktorFaktor Yang Mempengaruhi Profitabilitas Perusahaan Di Indonesia (Studi Kasus : Indeks LQ45 Periode 2012-2016). Management Insight Vol.14 No.1:36-50

Kusomo, Y.C ., dan Darmawan, A (2018). Pengaruh perputaran modal kerja, ukuran perusahaan, danDiversifikasi terhadap profitabilitas.Jurnal administrasi bisnis. Vol.57 No.1.

Kurniawati, Endang, dan Nila (2015). Pengaruh Financial Leverage Terhadap Profitabilitas. Jurnal Administrasi Bisnis (JAB). Vol.1 No.1 Januari 2015

Linda, Indriani, 2005, Hubungan Laba Akuntansi, Nilai Buku, dan Total Arus Kas Dengan Market Value : Studi Akuntansi Relevansi Nilai : Jurnal Riset Akuntansi Indonesia, Vol 8 No 3 : 286309.

Marusya, Pontororing dan Magantar, Mariam. (2016). Pengaruh Struktur Modal terhadap Profitabilitas pada 
Perusahaan Tobacco Manufacturers yang terdaftar di Bursa Efek Indonesia (BEI)Periode 2008-2015.Jurnal Berkala Ilmiah Efisiensi. Volume 16 No. 03, hlm: 484-492

Margaretha, Farah dan Khairunnisa. 2016. Pengaruh Struktur Modal dan Likuiditas terhadap Profitabilitas pada Usaha Kecil dan Menengah di Indonesia. Jakarta: Jurnal fakultas ekonomi dan bisnis trisakti.

Meidiyustiani, R. (2016). Pengaruh Modal Kerja, Ukuran Perusahaan, Pertumbuhan Penjualan Dan Likuiditas Terhadap Profitabilitas Pada Perusahaan Manufaktur Sektor Industri Barang Konsumsi Yang Terdaftra Di Bursa Efek Indonesia. Universitas Budi Luhur. Jurnal Akuntansi dan Keuangan. Vol.5 No. 2

Nugroho, Nur Cahyo. (2014). Analisis Pengaruh Profitabilitas, Pertumbuhan Penjualan, Ukuran Perusahaan, dan Umur Perusahaan Terhadap Struktur Modal Usaha Mikro Kecil dan Menengah Kerajinan Kuningan Di Kabupaten Pati. Management Analysis Journal, 3(2), 1-5.

Putranto, P., and Elan, K., 2018. Effect of Managerial Ownership and Profitability on Firm Value (Emprical Study on Food and Beverage Industrial Sector Company 2012 to 2015). European Journal Bussiness and Management , 10(25), 2018

Putranto, P.(2019). Pengaruh Strategi Diversifikasi, Leverage, dan Inflasi Terhadap Profitabilita: Studi empiris perusahaan food and beverages 20132018. Jurnal ilmu akuntan, Vol.4 No.2.

https://www.bps.go.id https://www.idx.co.id

https://www.cnbcindonesia.com

https://www.katadata.co.id

https://www.liputan6.com

https://www.kemenporin.go.id 